\title{
PENGARUH PENAMBAHAN ZEOLIT TERHADAP PENURUNAN AMONIAK DALAM LIMBAH CAIR INDUSTRI KARET
}

\author{
Nurlela ${ }^{1)}$, Husnah ${ }^{2)}$ \\ ${ }^{1,2}$ Dosen Tetap Program Studi Teknik Kimia Universitas PGRI Palembang \\ ${ }^{1)}$ email : Lela_dj79@yahoo.co.id \\ ${ }^{2)}$ email:husnahpgri@gmail.com
}

\begin{abstract}
Abstrak
Pengolahan industri karet banyak sekali menyisahkan limbah yang sangat mengganggu manusia dan lingkungan sekitar. Apabila limbah tersebut langsung dibuanga ke lingkungan sekitar, maka sangat berbahaya bagi manusia dan ekosistem. Limbah industri karet terutama crum raber mempunyai karakteristik yang cukup spesifik dan paling dominann yaitu kandungan amoniak terikat. Dimana dalam proses penetralisasinya sulit dilakukan dengan proses chemical. Salah satu proses yang dapat digunakan adalah proses penyerapan dengan menggunakan adsorban, Untuk itulah perlu dilakukan upaya penggunaan bahan penyerap yang ekonomis dan efektif seperti penggunaan zeolit. Adapun tujuan dari penelitian ini untuk mengetahui pengaruh penambahan zeolite terhadap penurunan kadar Amoniak dalam limbah cair industri karet.
\end{abstract}

Kata kunci : limbah karet, adsorpsi, zeolit

\section{PENDAHULUAN}

Sumatera Selatan merupakan salah satu Propinsi yang memiliki banyak perkebunan karet yang dikelola oleh pemerintah, swasta, maupun oleh rakyat dengan potensi besar tersebut, maka Sumatera Selatan khususnya kota Palembang banyak didirikan pabrik karet yang tentunya dalam kegiatan tersebut akan menghasilkan limbah. Jika perusahaan tidak mengelolah limbahnya terlebih dahulusebelum dibuang kesungai atau perairan umum maka sudah barang tentu akan menimbulkan dampak yang merugikan berupa kerusakan lingkungan terutama Sungai Musi, karena hampir semua perusahaan karet beroperasi disepanjang Sungai Musi dan membuang limbahnya ke Sungai Musi. (Anonimous,1997)

Sungai merupakan sumber pangan produktif bagi mahluk hidup termasuk manusia. Air Sungai Musi digunakan oleh penduduk untuk memenuhi kebutuhan sehari-hari misalnya: untuk mandi, mencuci, memasak dan untuk kebutuhan air minum. Untuk menjaga ekosistem perairan sungai, limbah cair tersebut harus diolah terlebih dahulu sebelum dialirkan ke sungai sesuai dengan peraturan yang telah ditetapkan oleh pemerintah.

Limbah cair yang dihasilkan oleh beberapa industri karet diolah menggunakan beberapa cara diantaranya secara kimia dan bioligi. Pengolahan limbah cair secara kimia adalah dengan menggunakan bahan kimia seperti PAC (Poly Alumunium Chloride) untuk memperoleh angka penurunan BOD, COD, TSS dan nilai $\mathrm{pH}$ agar memenuhi Baku Mutu Limbah cair. Akan tetapi 
penggunaan bahan tersebut tidak efektif menurunkan angka $\mathrm{NH}_{3}$, sehingga masih masih berada diatas baku mutu (Moelyadi, 1990)

Masalah ini cukup menarik untuk diteliti, yaitu bagaimana menurunkan kadar amoniak yang ada pada limbah cair industry karet, sehingga memenuhi Baku Mutu Limbah Cair Industri Karet.

\section{TINJAUAN PUSTAKA \\ Karet (Hevea)}

Karet adalah tanaman yang berasal dari Negara berazil, Amerika Selatan. Karet merupakan salah satu komoditi perkebunan yang penting dalam program pembangunan nasional, khususnya pembangunan sektor pertanian. upaya pengembangan komoditas karet telah diusahakan secara terusmenerusbbaik oleh pemerintah maupun oleh swasta (Erwin, 1998).

Adapun manfaat karet yaitu:

1. Untuk digunakan dalam berbagai keperluan antara lain sebagai bahan pembuatan ban motor, ban mobil, bola dan lain lain

2. Dapt digunakan juga sebagai bahan penghapus dan bahan untuk menyalakan api.

\section{Teori Adsorpsi}

Adsorpsi mupakan suatu zat yang melibatkan akumulasi pada permukaan antara dua fase, misalnya fase cair dan padatan atau gas dan padatan. Secara singkat dapat dikatakan bahwa prosesadsorpsi adalahpenumpukan (akumulasi) bahan pada permukaan adsorben. Zat yang diadsorbsi (pada permukaan) disebut adsorbat atau solute dan zat yang mengadsorpsi atau padatan tempat terjadinya adsorpsi di sebut adsorben.

Sifat permukaan zat padat yang dapat digunakan sebagai adsorben sangat penting untuk diketahui. Pada semua zat padat dapat mengikat atau menyerap molekul, akan tetapi untuk pemisahan hanya adsorbrn yang selektif yang sangat berguna. Adsorben yang baik, selain selektif juga harus mempunyai luas permukaan yang cukup, oleh karena itu adsorbrn memiliki pori-pori (Reynolds,1982).

Molekul yang terserap akan terkumpul dipermukaan dan menjadi lebih rapat, maka akan terjadi perubahan fase molekul dari gas menjadi cair atau cair menjadi padat. Adanya perubahn fase tersebut menyebabkan penyerapan selalu dibarengi dengan pelepasan kalor yang disebut sebagai panas adsorpsi.

\section{Zeolit}

Istilah zeolite berasal dari kata "zein" (bahasa Yunani) yang berarti membuih dan "lithos" yang berarti batu. Nama ini sesuai dengan karakter/sifat zeolite yang akan membuih bila dipanaskan (Rifin. dkk, 2001).

Zeolit merupakan mineral yang terdiri dari Kristal aluminosilikat terhidrasi yang mengandung kation alkali atau alkali tanah dalam kerangka tiga dimensinya. Ion-ion logam tersebut dapat diganti oleh kation lagi tanpa merusak struktur zeolite yang dapat menyerap air secara reversible

Zeolit mempunyai struktur berongga dan biasanya rongga ini diisi oleh air dan kation yang bisa dipertukarkan dan memiliki ukuran pori yang tertentu. Oleh sebab itu zeolite dapat dimanaatkan sebagai penyerap bahan, penyaring molecular, katalisator dan penukar ion.

Banyak mineral zeolite di Indosensia, karena sebagian besar wilayah Indonesia terdiri dari gunung berapi yang memiliki larva-larva gungung api yang banyak mengandung zeolite (Hidayat, 2009)

Mineral zeolite alam sebenarnya dikenal sejak jaman Romawi kuno tetapi terbatas pada pemanfaatan untuk bangunan, ornament dan plester. Penggunaan zeolite alam pada prisipnya sama 
dengan mineral zeolite sintetis karena kedua jenis zeolite tersebut mempunyai persamaan fisik dan kimia, meskipun mempunyai beberapa perbedaan siat fisika dan kimia.

Salah satu kegunaan zeolite adalah untuk pengelolaan air. Air yang dimaksud adalah air yang berasal dari air tanah, air suling, limbahindustri, limbah rumah tangga dan juga limbah pertanian. Air kotor ini mengandung limbah yang tidak larut, bahan terlarut dan koloid. Sehingga air kotor harus ditangani secara mekanis, kimia dan biologi tergantung dari kotoran dan bahan pencemarnya serta setandar air bersih yang diperlukan.

\section{Karakteristik Air Limbah Pabrik Karet}

Karakterisrik air limbah industri karet terdiri dari karakteristik fisika dan kimia Karakteristik fisika meliputi:

- Padat Tersuspensi Total (TSS)

- Temperatur

- Kekeruhan

- Bau

- Warna

Karakteristik Kimia terdiri dari:

- $\operatorname{Keasaman}(\mathrm{pH})$

- Chemical Oxygen Demand (COD)

- Biologycal Oxygen Demand (BOD)

- Amoniak $\left(\mathrm{NH}_{3}\right)$

Parameter-parameter yang penting untuk mengukur kualitas limbah cair industry karet adalah BOD, COD, TSS, $\mathrm{pH}, \mathrm{NH}_{3}$ dan Total Nitrogen. Tingginya nilai COD dan BOD disebabkan banyaknya kandungan zat-zat organic yang terlarut di dalam air limbah. Sedangkan keberadaan amoniak dan senyawa mikroba dan tingginya nilai TSS disebabkan banyaknya kandungan lumpur dan total yang terdapat pada bahan baku karet yang diolah, serta nilai $\mathrm{pH}$ yang rendah disebabkan oleh penggunaan asam semut yang digunakan untuk mengumpulkan karet.

Parameter-parameter yang mempunyai nilai diambang batas tersebut, menunjukkan perlunya dilakukan pengolahan terlebih dahulu terhadap limbah cair industri karet sebelum dikembalikan kebadan sungai

\section{METODOLOGI PENELITIAN}

Pada penelirian ini menggunakan alat: Spektrootometer, Gelas ukur, Labu ukur, Pemanas. Bahan yang digunakan: Air suling bebas amoniak, Pereaksi Nessler, Larutan baku ammonium.

\section{Prinsip Kerja}

Pereaksi Nessler $\left(\mathrm{K}_{2} \mathrm{HgI}_{4}\right)$ dalam susunan basa kuat dengan nitrogen amonia $\left(\mathrm{N}^{\left.-\mathrm{NH}_{3}\right)}\right.$ yang terdapat dalam air membentuk golongan warna kuning coklat yang sebanding dengan kadar ammonia dan dibandingkan dengan warna standar ammonia dan diperiksa dengan Spektrofotometer pada panjang gelombang maksimum yang diserap oleh larutan standar yang memiliki konsentrasi tinggi yaitu pada panjang gelombang $480 \mathrm{~nm}$. 


\section{HASIL DAN PEMBAHASAN}

Dari hasil analisa penentuan kadar amoniak setelah perlakuan variable berat zeolit maka didapat data sebagai berikut:

Tabel 1. Penambahan Zeolit 40 mesh

\begin{tabular}{|c|c|c|c|c|}
\hline $\begin{array}{c}\text { Berat Zeolit } \\
(\mathbf{g r})\end{array}$ & $\begin{array}{c}\text { Volume } \\
\text { Limbah }(\mathbf{m l})\end{array}$ & $\begin{array}{c}\text { Faktor } \\
\text { Pengenceran }\end{array}$ & Absorbans & $\begin{array}{c}\text { Kadar NH3 } \\
(\mathbf{m g} / \mathbf{l})\end{array}$ \\
\hline 5 & 100 & 10 & 0,501 & 50,14 \\
10 & 100 & 10 & 0,313 & 31,31 \\
20 & 100 & 10 & 0,270 & 27,02 \\
30 & 100 & 10 & 0,232 & 23,23 \\
40 & 100 & 10 & 0,208 & 20,84 \\
\hline
\end{tabular}

Dari data tabel penambahan zeolite terhadap kadar Amoniak didapatkan hasil grafik seperti dibawah ini:

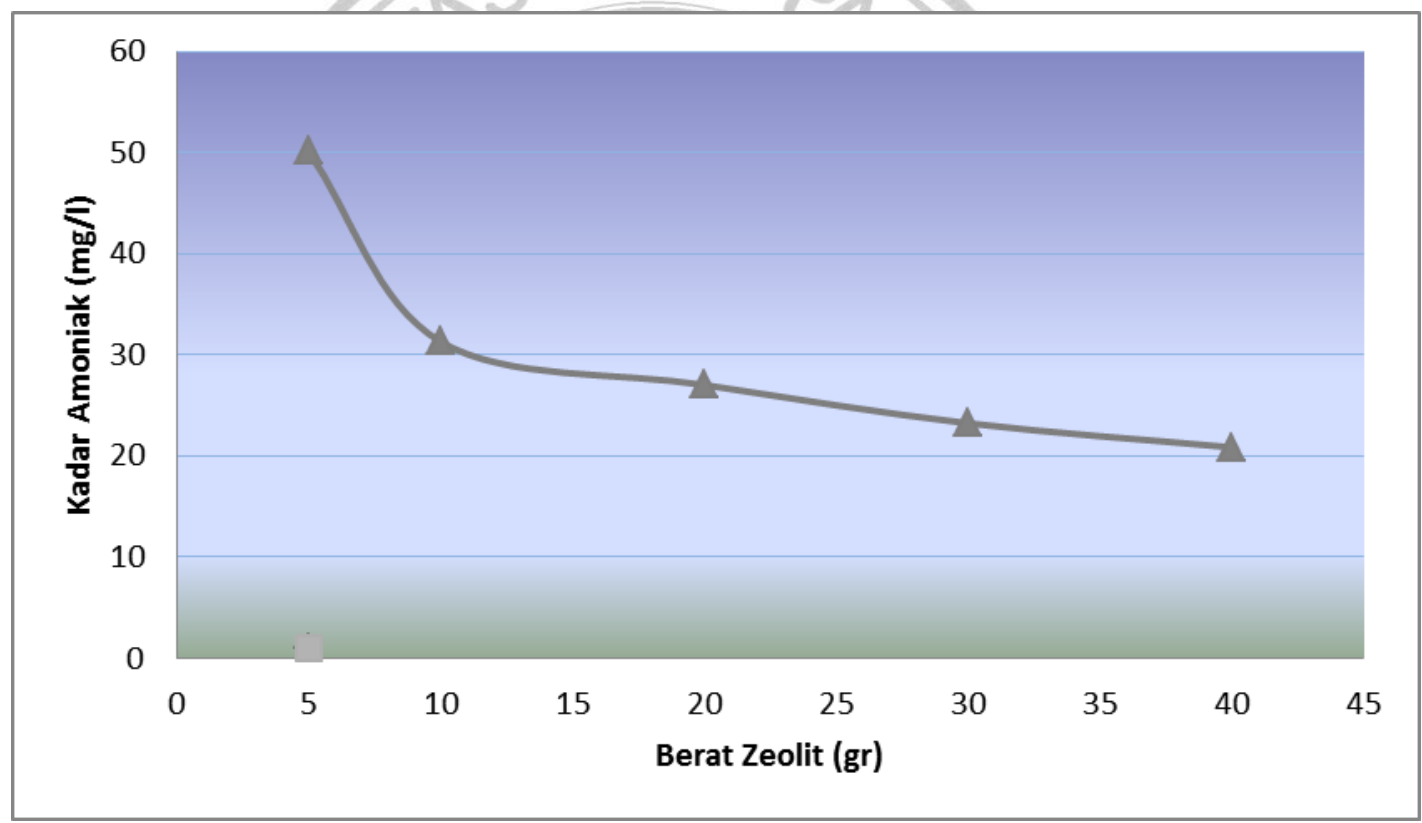

Gambar 1. Penambahan Zeolit Terhadap Daya Serap $\mathrm{NH}_{3}$

Penambahan Zeolit ukuran 40 mesh dengan berat 5 gram kadar $\mathrm{NH}_{3}-\mathrm{N}$ sebesat $50,14 \mathrm{mg} / \mathrm{l}$. Sedangkan. Pada penambahan 40 gram zeolite dengan volume limbah yang sama maka didapat kadar NH3-N sebesar 20,84 mg/l. Maka seiring dengan dengan laju penambahan berat Zeolit terjadi penurunan kadar Amoniak. Semakin banyak penambahan zeolite maka terjadi penurunan kadar pencemar amoniak. 


\section{KESIMPULAN}

Dari hasil Penelitian Pengolahan Limbah Cair Industri Karet yang telah dilakukan maka didapatkan kesimpulan :

- Zeolit dapat digunakan untuk menurunkan kadar amoniak pada limbah cair industry karet

- Zeolit alam yang telah diaktifasi dapat digunakan untuk bahan penyerap air limbah

- Semakin banyak zeolite yang ditambahkan maka semakin baik daya serap terhadap amoniak.

\section{DAFTAR PUSTAKA}

Anonimous, Dinamika Penelitian BIP A, Vol 5 No.9 Balai Penelitian dan Pengembangan Industri Palembang, 1997

Erwin Tunas: Awi Aman. Penerapan Produksi BersihPada Industri Crum Rabber dan Kendala Yang Dihadapi, Gapindo 1998

Hidayat, Hedi; Syahrial. "Laporan dan Pendataan dan inventarisasi endapan zeolite Indonesia". Pusat Pengembangan Teknologi Mineral Bandung 2009

Moelyadi Moelya. Sumber Pencemaran dan Karakteristik Air Limbah. Puslitbang Pengairan Dep. PU Bandung, 1990

Reynolds, T.D. 1982. "Unit Operations and Process in Environmental Engineering", Texas A \& M University, Books/Cole Engineering Division, Monterey, California, USA, pp 165 - 166.

Rifin, Masri, Koswara, Yayat. "Laporan Penyelidikan Pendahuluan dan Pengumpulan data endapan Zeolit. Jakarta 2001 